Процик, Ірина. «„В футбол треба грати неодмінно!” Футбольна термінолексика художніх творів Юрія Смолича як репрезентація українського футбольного дискурсу в Наддніпрянській Україні в першій половині XX століття». Лінгвостилістичні студї, вип. 10, 2019, с. 163-185.

Protsyk, Iryna. “"You Ought to Play Football!” Football Terminology in the Literary Works by Yurii Smolych as Representation of the Ukrainian Football Discourse in the Naddniprianshchna Regional Lexicon in the First Half of the XX ${ }^{\text {th }}$ Century". Linguostylistic Studies, iss. 10, 2019, pp. 163-185.

УДК 811.161.2'276.6

https://doi.org/10.29038/2413-0923-2019-10-163-185

\title{
«В ФУТБОЛ ТРЕБА ГРАТИ НЕОДМІННО!» ФУТБОЛЬНА ТЕРМІНОЛЕКСИКА \\ ХУДОЖНІХ ТВОРІВ ЮРІЯ СМОЛИЧА ЯК РЕПРЕЗЕНТАЦІЯ УКРАЇНСЬКОГО ФУТБОЛЬНОГО ДИСКУРСУ В НАДДНІПРЯНСЬКІЙ УКРАЇНІ В ПЕРШІЙ ПОЛОВИНІ ХХ СТОЛІТТЯ
}

\author{
Ірина Процик \\ Національний університет «Києво-Могилянська академія», \\ Київ, Україна
}

Статтю присвячено аналізові основних тематичних груп футбольної термінолексики, яка функціює в художніх текстах Юрія Смолича. Зафіксовані футбольні назви зіставлено з футбольними найменуваннями, які вживали в Галичині до Другої світової війни. 3'ясовано, що художні твори Юрія Смолича містять надзвичайно цінний фактичний матеріал, який відображає особливості розвитку українського футбольного дискурсу в Наддніпрянській Україні в першій половині XX століття.

Ключові слова: український футбольний дискурс, Юрій Смолич, художній текст, футбольна термінолексика, тематичні групи футбольної лексики.

Protsyk Iryna. "You Ought to Play Football!" Football Terminology in the Literary Works by Yurii Smolych as Representation of the Ukrainian Football Discourse in the Naddniprianshchna Regional Lexicon in the First Half of the $\mathrm{XX}^{\text {th }}$ Century. Diachronic analysis of the football terminology creation in the Ukrainian language does not only allow reviewing its functioning in special contexts which are usual for this layer of vocabulary, but also provides a basis for determining the use of the football nominations in the literary texts. Yurii Smolych is practically the only writer from Naddniprianshchyna region of the interwar period who touched on the football topic in his literary works. That is why the review of his texts is very important for clarifying the specificity of the Ukrainian football nominations development in the Naddniprianshchyna region. The main goal of the research is the analysis of the selected football lexicon from the literary works by Yurii Smolych. Comparison of it with special football nominations which functioned for naming the same football notions in Halychyna before World War II can provide further opportunities for tracing peculiarities of the Ukrainian football discourse in Naddniprianshchyna in the first half of the XX century.

The analysis of the Ukrainian football vocabulary which was used in Yurii Smolych's literary texts has revealed that the author uses extremely wide range of special football terms. The analyzed 19 groups of football nominations manifest that the foreign loanwords in names

(C) Процик I., Східноєвропейський національний університет імені Лесі Українки, 2019.

Це стаття відкритого доступу на умовах CC BY-NC 4.0 
of a football game, its parts and football tournaments, names of a team and unions of teams, names of the game moments dominate. The majority of the original names concern the lines of football players on the playing field, names of fans and their actions. Both the loanwords and genuine Ukrainian nominations are the base of the groups denoting names of football uniform and the results of football games and their quantitative indicators. Ukrainian lexemes and hybrid derivatives form the main part of the nominations regarding football equipment, names of football actions, variety of kicks, training activities, names regarding peculiarities of a football game, whereas foreign loanwords prevail in the nominations of football players and the names of a football field and its parts. Thus, in his literary works Yurii Smolych has involved various lexical units concerning the most important thematic groups of football lexicon in which loanwords and hybrid nominations prevail. It is characteristic of the football discourse in Naddniprianshchyna, unlike the football language in Halychyna, where genuine Ukrainian nominations prevailed over loanwords in the first half of the XX century.

Key words: Ukrainian football discourse, Yurii Smolych, literary text, football terminology, thematic groups of football names.

Товаришу! Чи граєте ви у футбол? В футбол треба грати неодмінно. Це прекрасний спорт. Він виховує завзяття до боротьби, відважність, меткість, кмітливість, наполегливість. Він гартує і дух, і тіло. Він виховує ціле тіло - від пружності пальців ніг і до швидкості ока. Він гартує людину на все їі дальше життя. Прекрасний, незабутній футбол!

Юрій Смолич, «Наші тайни»

Вступ. Український футбольний дискурс викликає щоразу більше зацікавлення мовознавців. В українській лінгвістиці $\epsilon$ грунтовне дослідження сучасної футбольної лексики початку XXI ст. (численні статті та дисертація Юрія Струганця). Проте досі бракує студій про розвиток української футбольної термінолексики на діахронному зрізі. Аналіз історії формування футбольної лексики в українській мові передбачає, окрім розгляду її функціювання в звичних для цього пласта лексики спеціальних контекстах (текстах наукового та публіцистичного стилів), також опис використання футбольних номінацій у текстах художнього стилю. Коли йдеться про футбольну термінолексику першої половини XX ст., то її вживання в художніх творах демонструють насамперед тексти письменників-галичан (новелістика та драматургія Івана Керницького, мала проза Івана Смолія та Зенона Тарнавського (Процик, «На ціле життя»; Процик, «Функціонування»)), а серед авторів-наддніпрянців чи не єдиним представником, який порушив футбольну тематику, є Юрій Смолич. Тому розгляд спеціальних футбольних назв у його художніх творах $\epsilon$ актуальним для з'ясування специфіки розвитку українського футбольного дискурсу в Наддніпрянщині в першій половині XX ст.

Мета дослідження - на основі аналізу відібраної з художніх творів Юрія Смолича футбольної лексики та зіставлення її зі спеціальними футбольними номінаціями, які функціювали на позначення тих самих футбольних понять у Галичині, простежити особливості українського футбольного дискурсу в Наддніпрянській Україні в першій половині ХХ ст.

Матеріал i методи дослідження. Опис специфіки розвитку наддніпрянського футбольного дискурсу першої половини XX ст. 
здійснено на основі аналізу футбольної термінної лексики, зафіксованої в романі Юрія Смолича «Наші тайни» і в белетризованих спогадах «Я вибираю літературу», та порівнянні іï зі спеціальною футбольною лексикою, яка функціювала в міжвоєнний період у Галичині. У статті використано такі методи дослідження - описовий (для систематизації виокремлених лексем), порівняльний (для зіставлення футбольних назв, уживаних у футбольному дискурсі Наддніпрянщини у першій половині XX ст., із футбольними номінаціями, що функціювали в той самий хронологічний період у Галичині) та метод кількісних підрахунків (для визначення частотності вживання лексем). Для тематичного поділу футбольних назв застосовано власну класифікацію, запропоновану в розвідці про українську футбольну термінолексику кінця XIX - початку XX ст. (Процик, «Копаний м'яч»).

Результати дослідження та дискусія. Юрій Смолич - автор, завдяки якому українська література має художні твори, що порушують футбольну тематику, - 3 юних літ був захоплений копаним м'ячем, понад десять років свого життя активно виступав за різні футбольні команди Поділля, а слово футбол вимовляв, як сам зізнавався, «із знаком оклику» (Смолич, «Я вибираю» 582). Художні тексти Юрія Смоличана футбольні теми важливі для української лексикології та соціолінгвістики насамперед як безцінне джерело фактичного матеріалу, адже, знаючи грунтовно всі нюанси гри, автор представив у творах широкий спектр футбольної лексики, яка функціювала у футбольному дискурсі Наддніпрянщини в першій половині XX ст. Аналіз прикладів зі згаданих вище художніх творів, дає підстави стверджувати, що в них охоплено футбольну термінолексику різних тематичних груп, зокрема:

назва гри: фбутбол «Книжка і футбол - цим, либонь, вичерпувалося для Макара все його п'ятнадцятилітнє життя» (Смолич, «Наші тайни» 147), «В книзі, яку я пишу про себе, - раз я вже взявся до таких нотаток, - я не можу не записати про футбол» (Смолич, «Я вибираю» 582), грище лексему вжито в значенні 'гра у футбол, ігрище' «Хоча от уже мало не півстоліття після того, як сам зійшов з футбольного поля, теж належу до когорти вболівальників цього чудодійного грища» (Смолич, «Я вибираю» 582); назва футббол функціює також у складі словосполук: вітчизняний футтбол «Кінець кінцем в ці півстоліття вкладається майже вся історія вітчизняного футбола» (Смолич, «Я вибираю» 602), «великий футтбол» 'професійний футбол' «Я мріяв про «великий футбол» - про той футбол, який маю тепер тільки як болільник» (Смолич, «Я вибираю» 600); як видно із запропонованих контекстів, Юрій Смолич послідовно використовує запозичену лексему футбол; рідше уживано питому номінацію грище як єдиного українського відповідника до чужомовної назви; у той час, коли галичани вживали низку власних аналогів до терміна-англізму (гра в копаний м'яч, гра в м'яч, копаний ногами, копана, копаний м'яч, копанка, 
м'яч, м’яч, копаний ногами), наддніпрянці надавали перевагу інтернаціоналізмові футбол;

назви футбольного поєдинку, його частин, а також футбольних турнірів: мamч «Mamч ми прийняли десять проти одинадцяти» (Смолич, «Наші тайни» 162), «Не пригадую вже чому, з якої нагоди - мабуть згадавши про приїзд нашої колишньої футбольної команди на матч до Одеси та мою участь у тому матчі, - я розповідав дружині взагалі про моє футболістське минуле» (Смолич, «Я вибираю» 583); лексема матч $є$ й елементом складних і складених футбольних номінацій: матч-відповідь «Влітку, либонь, двадцять першого року нашу інструкторську команду жмеринського всеобучу відряджено до Одеси на матч-відnовідь 3 «Вегою»» (Смолич, «Я вибираю» 595), матч-ревани «<...> ми граємо у них, і разом 3 нами вони їдуть до Жмеринки - на матч-реванш» (Смолич, «Я вибираю» 596), футбольний матч «Футбольні матчі збуджують почуття патріотизму в людині взагалі, так би мовити, вчать бути патріотом» (Смолич, «Я вибираю» 585), міжсміський матч «За рік чи два почались і наші міжміські матчі» (Смолич, «Я вибираю» 588-589), міжзональний матч «Але найбільш цікаві були матчі міжзональні» (Смолич, «Я вибираю» 594), гра «Ми несли зараз в собі надзвичайне піднесення після фізичної радості гри і після нового, не знаного ще, духовного екстазу» (Смолич, «Наші тайни» 137-138), товариська гра «<..> я ще грав у футбол, але то вже були не організовані матчі, а тільки звичайна товариська гра» (Смолич, «Я вибираю» 600), тайм «Він читав завжди і скрізь. Вдома, в перерві між таймами, в убиральні, під час обіду, на всіх лекціях» (Смолич, «Наші тайни» 147), перший тайм «Перший тайм закінчився з рахунком 2:0 на користь чехів» (Смолич, «Я вибираю» 589), другий тайм «Другий тайм почався навальною атакою офіцерів - вони хотіли за всяку ціну відігратися <...> (Смолич, «Я вибираю» 589), перерва «То, сполошена несподіваною перервою в грі, бігла сюди ворожа команда» (Смолич, «Наші тайни» 136), міжсміське змагання - 'міжміський матч' «Хіба до деклінацій та кон'югацій було, коли треба було відбути цілу низку найвідповідальніших міжміських змагань в гонитві за «очками», які давали право пройти в лігові команди?» (Смолич, «Наші тайни» 149); периість - 'чемпіонат', змагання на кубок- 'кубковий матч' «Взяти два очка (за першість) або вибити партнера із змагання (на кубок)» (Смолич, «Я вибираю» 591), футбольна першість «Звичайно, десь по великих містах - у Києві, Одесі, Петрограді, а надто в містах, що того часу боролись за футбольну першість по цілій країні <...>» (Смолич, «Я вибираю» 591); серед назв футбольного поєдинку частотність вживання запозиченої 3 англійської мови лексеми матч суттєво переважає над функціюванням питомих номінацій гра та змагання; для називання половини гри використано лише чужомовне запозичення тайм (вживаних у Галичині українських відповідників - півгра та половина - не зафіксовано), а на позначення паузи між таймами вжито, суголосно з галичанами, власне 
українську назву перерва; для найменування чемпіонату функціювала власне українська лексема першість;

назви команди та об'єднань команд: команда «I ми були футболісти одної команди» (Смолич, «Наші тайни» 137), «Після того наша команда враз розтанула - футболісти пурхнули хто куди» (Смолич, «Я вибираю» 598), футбольна команда «Адже кожний полк мав свою футбольну команду» (Смолич, «Наші тайни» 141), «Саме тому, очевидно, більшість тогочасних (провінціальних) футбольних команд мали форму: білі труси» (Смолич, «Я вибираю» 586), одинадцятеро - ‘футбольна команда' «Ми - одинадцятеро - йшли в ряд широким строєм, на всю широчінь вузенької вулички передмістя» (Смолич, «Наші тайни» 137), одинадцять футболістів - 'футбольна команда' «Виїздили ми спеціальним вагоном - вантажною теплушкою: одинадцять футболістів і наша ж, всеобучівська, музикальна команда - духовий оркестр залізничників» (Смолич, «Я вибираю» 595), лігова бутбольна команда «Але в провінції, зокрема в нашій Жмеринці, футбольні команди були не лігові <...>» (Смолич, «Я вибираю» 591), збірна команда «Матч з Одесою зі збірною командою одеських середніх шкіл - відбувався своєчасно» (Смолич, «Наші тайни» 161), жсмеринська команда футболістів (ЖКФ) «Розповідав, що наша жмеринська команда футболістів (ЖКФ) складалася переважно з голитьби - дітей залізничних робітників, і ми не мали змоги придбати не тільки спортивний одяг, але й бутси та самий футбольний м'яч» (Смолич, «Я вибираю» 583-584), жсмеринська команда «Четверо братів Тубакаєвих теж грали в нашій жмеринській команді» (Смолич, «Я вибираю» 584), перша / друга збірна «Складалась ЖФКЗ в основному 3 гравців колишніх «збірних» - першої та другої <...>» (Смолич, «Я вибираю» 594), (периа / друга) збірна командаміста «Адже мої перші футбольні спроби були ще в дванадцятому та тринадцятому роках нашого століття, а сам, мавши лише чотирнадцять років зроду, вже грав форварда у першій (бо була ще - друга) збірній команді нашого міста» (Смолич, «Я вибираю» 585), вулична команда, загальноміська команда, клубна команда, клуб «Команда відразу ж перестала бути вуличною, а стала, так би мовити, загальноміською, коли б на теперішню термінологію, то - клубною. Тільки от клубу і не було» (Смолич, «Я вибираю» 587), друга команда «Грали ми здебільшого з другою командою, що утворилась на іншому передмісті Новий План - і справила собі сорочки модного тоді кольору «танго», тобто жовтогарячі» (Смолич, «Я вибираю» 588), одеські команди ОКФ, «Вега», «Макабі» «Грали найчастіше з сусідньою Вінницею - командами учнів реального училища чи залізничників; і з одеськими командами ОКФ, «Вега», «Макабі»» (Смолич, «Я вибираю» 589), команда високого класу «Була це команда високого класу - футбол у Чехії на той час був дуже популярний, i чеські команди тримали світову першість» (Смолич, «Я вибираю» 589), чеська команда, клубна команда «Наша полоненська чеська команда склалася з гравців різних за мирного часу чеських клубних команд <...> 
(Смолич, «Я вибираю» 589), ЖКФ, команда чехів «<..> матчі нашої ЖКФ проти команди чехів були для нас доброю школою» (Смолич, «Я вибираю» 589), Всеросійська футтбольна ліга «<... футбольні команди входили до всеросійської футбольної Ліги <...>» (Смолич, «Я вибираю» 591), ворожа команда «То, сполошена несподіваною перервою в грі, бігла сюди ворожа команда» (Смолич, «Наші тайни» 136), противна команда «Правда, наш стиль гри був цікавий лише при однаковій кваліфікації противних команд» (Смолич, «Я вибираю» 593), інструкторська футбольна команда «<..> при повітових військкоматах, які відали цілою округою допризовних формувань, утворились і спеціальні інструкторські футбольні команди» (Смолич, «Я вибираю» 594), інструкторська команда, команда залізничників, ЖФКЗ «Жмеринський повітовий військкомат інструкторською командою всеобучу оголосив нашу команду залізничників тоді ми вже привласнили собі назву ЖФКЗ» (Смолич, «Я вибираю» 594), «Арма», «Спортінг» «Грали 3 Вінницею - 3 командами «Арма» i «Спортінг»...» (Смолич, «Я вибираю» 594), команди«Вега», «Англійський клуб» «3 Одеси до нас приїздила команда «Вега» - відомий 3 дореволюційних і довоєнних часів суперник у претензіях на першість Одеси в змаганні з славнозвісною командою "Англійський клуб»» (Смолич, «Я вибираю» 594-595), команда у повному складі «Команда знайшлась $у$ повному складі і згоду дала охоче <...» (Смолич, «Я вибираю» 596); на позначення об'єднання футболістів послідовно вживано запозиченої назви команда (як самостійного терміна, так і складника словосполучень), українського відповідника - дружина (вживаного в Галичині) - не зафіксовано; питома лексема збірна та чужомовне запозичення клуб функціювали рівнобіжно у футбольному дискурсі Сходу та Заходу України;

назва футбольного майданчика та його частин: футбольне поле «Ми не могли вже жити один без одного і за межами футбольного поля» (Смолич, «Наші тайни» 138), «Та хай там хоч що - от уже мало не півстоліття, як я не граю у футбол, але й за п'ятдесят минулих літ я не забув того почуття радості, якого зазнавав на футбольному полі під час матчу» (Смолич, «Я вибираю» 585), чуже поле «Дарма що на чужому полі, одесити наклепали нам» (Смолич, «Наші тайни» 162), корнерний ріжок 'місце пробивання кутового удару', середина поля «Духовий оркестр патетично вдаряв, і багатотисячною зграєю злітали лопотливі оплески запальних глядачів: 3 корнерних ріжків, одна проти одної, команди вибігали короткими ключами до середини поля» (Смолич, «Наші тайни» 161), межі поля «Капітани команд тисли один одному руки й обмінювалися букетами, які зразу ж забирали і виносили за межі поля підсудки» (Смолич, «Наші тайни» 161), край [поля] ««Водились» тільки по краях, і те - в дрібній пасовці між краєм і хаубеком або інсайдом» (ЯВЛ, с.592), правий край [поля] «Потім враз <..> сильним шутом послав м'яч далеко через поле на правий край» (Смолич, «Наші тайни»162), правий фбланг «Але в нашій команді якраз я і був забивачем м'ячів: я йшов на пас 3 
правого фланга - «налітав», як ми тоді казали, - і забивав гол: правою, лівою, «датським», «англійським», «бейтом», головою, грудьми - як прийдеться» (Смолич, «Я вибираю» 593), «корнер» - 'місце пробивання кутових ударів', центр [поля], пенальті - 'одинадцятиметрова позначка' «Отже, він розмічений не був - відзначено тільки «корнери», центр і пенальті» (Смолич, «Я вибираю» 587), штрафний майданчик «Я, наприклад, не мав надто сильного удару - з-поза меж штрафного майданчика я, мабуть, за все своє футбольне життя не забив жодного м'яча» (Смолич, «Я вибираю» 593), своя половина поля, край, центр «Захист в наш час грав виключно зонально: беки пильнували штрафного майданчика, хаубеки - кожний своєї половини поля: лівий - зліва до центру, правий - справа, а центральний хаубек завжди йшов висунутий наперед, щоб «підбирати» м'ячі позаду лінії свого нападу і або зразу шутувати по голу через голову свого центрфорварда, або розподіляти м'ячі між інсайдами - для дрібної пасовки, або краями - якщо центр противника виявлявся непробивним» (Смолич, «Я вибираю» 592-593), на позначення футбольного майданчика в східноукраїнському футбольному дискурсі безконкуренційно функціював термін футбольне поле (номінацій грище, ігрище, мурава, вживаних у Галичині, не зафіксовано); фланг названо питомою лексемою край і згаданим запозиченням; вживане в галицькому футбольному дискурсі питоме найменування крило в текстах Юрія Смолича не використано; гібридний термін штрафний майданчик - єдина номінація на позначення цієї частини футбольного поля в наддніпрянському футбольному дискурсі, в той час, як галичани використовували власне українські назви карне поле, карний пояс, займа; цікавою $є$ тенденція появи багатозначності, коли лексема йменує різновид удару та місце, з якого його виконують, наприклад, пенальті, корнер (паралельно з цією назвою на позначення точки чи сектора, звідки пробивають такий удар, функціював гібридний термін корнерний ріжок, а в Галичині вживали номінації вугол, кут, ріг); у галицькому футбольному дискурсі багатозначності вдалося уникнути завдяки тому, що для позначення місця пробивання пенальті використовували назви карна точка й одинадиятиметрівка, а термін пенальті / пенальді вживали лиш для називання самого удару, хоча паралельно з ним функціювали питомі терміни одинадиятиметровий і займак); на позначення кутового штрафного удару галичани, поряд із запозиченням корнер, вживали питомих номінацій коп з рога, копненє з кута, наріжник, наріжняк;

назви футбольної форми: буци - 'бутси' «От ми йшли стрункою, однодушною лавою, і гравій вулички шорстко рипів під шипами наших буців» (Смолич, «Наші тайни» 138), спортивний одяг, бутси «Розповідав, що наша жмеринська команда футболістів (ЖКФ) складалася переважно 3 голитьби - дітей залізничних робітників, і ми не мали змоги придбати не тільки спортивний одяг, але й бутси та самий футбольний м'яч» (Смолич, «Я вибираю» 583-584), футбольні бутси «До того ж ми невдовзі й взагалі 
навчилися робити собі добрі бутси із звичайнісіньких черевиків - ніяк не гірші проти фабричних, навіть міцніші» (Смолич, «Я вибираю» 588), шunu [бутсів] «Ця «структура» міцно притискала підошву до передка, а після того вже впоперек підошви дерев'яними гвіздками прибивалося й шипи суцільні смужки спиртового ремінця. Бутс виходив на славу!» (Смолич, «Я вибираю» 588), труси «А оскільки гроші на пошиття спеціальних трусів теж не в кожного були, то й бралися нишком від мам кальсони, обрізалися вище колін, зашивалися спереду - от тобі й труси!» (Смолич, «Я вибираю» 586), труси, фбуфайка - 'футболка' «Сині з червоними комірами фуфайки і чорні труси - це ми. Червоні з чорними комірами фуфайки і білі труси - це одесити» (Смолич, «Наші тайни» 161), сорочка кольору «танго» (жовтогаряча) «Грали ми здебільшого 3 другою командою, що утворилась на іншому передмісті - Новий План - і справила собі сорочки модного тоді кольору «танго», тобто жовтогарячі» (Смолич, «Я вибираю» 588), фборма, майка, труси «Справлено нам і форму: рожеві майки та чорні з червоними лампасами труси, видано замість бутсів солдатські черевики <...>» (Смолич, «Я вибираю» 594); 3-поміж назв спортивного взуття й одягу в текстах Юрія Смолича найчастотнішими є чужомовні лексеми бутси, буци (обидві назви були й у галицькому футбольному дискурсі), труси, фуфайка, майка та найменування сорочка, успадковане з праслов'янської мови; вживаних у Галичині питомих чи успадкованих назв футбольної форми - штанці, штанцята, сорочинка, а також гібридної номінації футболівки (футбольні черевики, бутси) - не зафіксовано;

назви ігрових моментів: пас, офбайд, зрізаний пас «Тепер на правому краю Кашин, прийнявши Сербинового паса, мав провести м'яч по краю, майже до корнерного прапорця, унеможливлюючи тим офсайд, i звідтіля давати зрізаний пас під гол» (Смолич, «Наші тайни» 162), гол 'здобуті ворота' «Програвали ми чехам і п'ять і десять голів» (Смолич, «Я вибираю» 589), nac - 'передавання м'яча партнерові', гол «3 трьох вдалих пасів Кашина - один був гарантований гол» (Смолич, «Наші тайни» 162), дрібна пасовка - 'короткий пас' ««Водились» тільки по краях, і те - в дрібній пасовці між краєм і хаубеком або інсайдом» (Смолич, «Я вибираю» 592), міжспасовка - 'перепасовування' «Мені ввижалося <...> як наперед, у наполегливому тренуванні, відпрацьовуються комбінації міжпасовки <...> (Смолич, «Я вибираю» 600), паралельний пас під гол - 'паралельний пас під ворота' «Інсайди, власне, самі не йшли з м'ячем: вони підігравали центрфорвардові: коли ж центр передавав на край, і край, вийшовши майже до корнерного прапорця, давав паралельний пас під гол, - інсайди виходили на шут» (Смолич, «Я вибираю» 593), комбінація «Адже під ворожим голом у нападі в наш час була фактично одна комбінація: якщо центр не пробивається у штрафний майданчик противника, то передає м'яч на край, а край пасує на гол» (Смолич, «Я вибираю» 593), удар, комбінація, перевага над противником, володіння м'ячем «Удар, комбінація, перевага над противником, що в цю хвилину змагається 3 
тобою за володіння м'ячем <...> (Смолич, «Я вибираю» 591), комбінація в наступі / обороні, удар ногою по м'ячу «Головне було - удар. Не комбінація в наступі чи обороні, а саме удар ногою по м'ячу: фут-бол!» (Смолич, «Я вибираю» 591), навальна комбінація, пасовка 'перепасовування' «<...>nасовка в центральній групі нападу - ось що мало ціну й захоплювало» (Смолич, «Я вибираю» 591), навальна атака «Але ми чехи - не відтягались в оборону, як це робиться завжди тепер проти навальної атаки противника» (Смолич, «Я вибираю» 589), фбiнm, «водіння» - 'оманний рух футболіста, за допомогою якого він намагається обдурити суперника, обіграти його «<... катаючи м'яча по землі та намагаючись відірватись од противника, ми поступово опановували мистецтвом фінта у «водінні»» (Смолич, «Я вибираю» 587), свисток 'сигнал судді' «Точно о четвертій тридцять завмерлу тишу поля розтинав короткий, збурний і різкий, як удар бича, свисток» (Смолич, «Я вибираю» 161), свисток рефбері «Точно о четвертій двадцять п'ять розтинався третій, і останній, довгий свисток рефері» (Смолич, «Наші тайни» 161), грання «Ми спортові віддавались не для того, щоб вигравати, а для того, щоб мати насолоду від самого грання» (Смолич, «Я вибираю» 591), гра в одні ворота «Не знаю, як тепер, а в наш час «ігровим тренуванням» звалась гра в одні ворота - свій напад проти свого захисту: п'ять форвардів проти трьох хаубеків та двох беків» (Смолич, «Я вибираю» 583), прорив «<..> і лише в хвилини небезпеки, прориву противника, переміщались назад, в глибину, на допомогу бекам» (Смолич, «Я вибираю» 592), персональна опіка - 'перебування захисника впродовж усього матчу біля нападника команди-супротивника' «Основа сучасного стилю гри персональна опіка нападника <...>» (Смолич, «Я вибираю» 592), сильний yдар «Я, наприклад, не мав надто сильного удару - з-поза меж штрафного майданчика я, мабуть, за все своє футбольне життя не забив жодного м'яча» (Смолич, «Я вибираю» 593), реванш «По-друге, матч 3 «Вегою» в жаданні реваншу» (Смолич, «Я вибираю» 594-595), травма «До того ж, певна річ, я зазнав не однієї травми на полі <..> і сам покалічив не одного супротивника» (Смолич, «Я вибираю» 582); серед лексем цієї тематичної групи нема домінування чужомовних назв, хоча для номінування деяких футбольних понять використано запозичення, тоді, як у Галичині, дібрано питомі відповідники, зокрема: пас - подавання, подання; офсайд відсторонь, поза грою, спалений, (але також офзайд, офсід); гол - ворота, (3)добуті ворота; комбінація - заграння; фінт, водіння - кивання; ціла низка понять має власне українські назви - удар (галицьке - коп, стріл), перевага, володіння м'ячем, грання, гра, прорив (гал. - пробій), свисток (гал. свист, знак свиставкою); найменування пасовка, міжпасовка утворено за російською словотвірною моделлю від чужомовної твірної основи; запозичену назву атака використовувано й у Наддніпрянщині, й у Галичині; 
назви футбольного спорядження: м'яч, футбольний м'яч «Перший раз я побачив футбольний м'яч, коли вчився в перших класах у Кам'янець-Подільській гімназії» (Смолич, «Я вибираю» 586), гол - 'ворота' «Від другого, супротивного, гола хутко тупотіли сюди одинадцять пар голих ніг» (Смолич, «Наші тайни» 136), ворожсий гол - 'ворожі ворота' «Адже під ворожим голом у нападі в наш час була фактично одна комбінація: якщо центр не пробивається у штрафний майданчик противника, то передає м'яч на край, а край пасує на гол» (Смолич, «Я вибираю» 593), «наш» гол - 'наші ворота' «Дарма що після інфарктів на стадіон уже не ходжу i дивлюсь матчі по телевізору, після пританцьовування дістаю задишку, а після м’яча, який влітає в «наш» 2ол, мушу вдаватись до валідолу чи нітрогліцерину» (Смолич, «Я вибираю» 585), корнерний прапорець - 'кутовий прапорець' «Коли футболіст біжить від корнерного прапорця до середини поля, щоб почати матч, він переживає найкращі хвилини свого життя» (Смолич, «Наші тайни» 161), ворота, жердина, сітка «Ворота якщо й робилися, то тільки з трьох жердин - про сітку за ворітьми навіть не чули» (Смолич, «Я вибираю» 586); з-поміж назв спортивного спорядження переважають, як і в галицькому футбольному дискурсі, власне українські назви: м'яч, жердина (гал. - жердка, стовп, стовпок), ворота, сітка (гал. - воротна cima); використано також гібридні найменування: корнерний прапорець (гал. - хоруговка, прапорець на тичці), футбольний м’яч та запозичена 3 англійської лексема гол - на позначення футбольних воріт, що спричиняло багатозначність цього терміна у східноукраїнському футбольному дискурсі;

назви футбольних гравців: футболіст «I ми були футболісти одної команди» (Смолич, «Наші тайни» 137), «Адже був я не просто футболістом, а - коли вдатися до історичних мірил - одним із покоління зачинателів цього виду спорту в нашій країні» (Смолич, «Я вибираю» 585), гравець «Щодо патріотизму, то футбол гартує його i у гравия, i в болільника» (Смолич, «Я вибираю» 585), футбольний гравець «В ті часи ще писалося такі афіші і так рекламувалося видатних футбольних гравців, наче гастролерів» (Смолич, «Я вибираю» 601), гравець футтбольної команди «<..> матч 3 «Вегою» не відбудеться: голод розігнав гравців футбольної команди по харчі по селах, і зібрати їх не стало змоги» (Смолич, «Я вибираю» 596), голкіпер - 'воротар', бек - 'захисник', хавбек 'півзахисник', форвард - 'нападник' «Голкіпер Піркес, беки Туровський та Воропаєв, хавбеки Жайворонок, Кульчицький, Зілов, форварди Кашин, Теменко, Репетюк, Сербин і Макар. Одинадцятеро. Як один» (Смолич, «Наші тайни» 138), «Беків було два - і тільки два; хаубеків - три, і тільки три; форвардів - п’ять, і неодмінно п’ять» (Смолич, «Я вибираю» 592), правий хавбек - 'правий півзахисник' «Васька Жайворонок - наш мікроскопічний на зріст правий хавбек, чорний, як антрацит, і з обличчям, подзьобаним лишаями, як завжди, біг попереду i гнавперед собою 
футбольний м'яч» (Смолич, «Наші тайни» 138), правий бек - 'правий захисник’ «Цю фотографію <...> подарував мені <..> Серьожка Боржаковський, наш тоді «правий бек»» (Смолич, «Я вибираю» 595), форвард, капітан команди «В першому взводі третьої роти був найкращий форвард нашого міста та, мабуть, і цілого Правобережжя, капітан полкової команди, рядовий стрілець Ворм» (Смолич, «Наші тайни» 142), центр-форвард - 'центральний нападник' «Не брав участі в нашому абордажі один тільки Левко Репетюк - капітан нашої команди і наш центр-форвард» (Смолич, «Наші тайни» 143), центрфорвард «А втім, всі вони й справді були добрі футболісти, і центрфорвард з кожного був відмінний» (Смолич, «Я вибираю» 588), центр - 'центральний нападник' «В одній із навальних комбінацій нашої команди - пасовка між двома інсайдами і центром під штафним майданчиком противника - наш центр Ч-кий зіткнувся з центром п'ятнадцятого полку» (Смолич, «Я вибираю» 589-590), край - 'крайній нападник' «Адже під ворожим голом у нападі в наш час була фактично одна комбінація: якщо центр не пробивається у штрафний майданчик противника, то передає м'яч на край, а край пасує на гол» (Смолич, «Я вибираю» 593), капітан, центрфорвард, футббольний лідер «<... капітаном і центрфорвардом був у ній Ч-кий - один із славнозвісних футбольних лідерів Чехії того часу» (Смолич, «Я вибираю» 589), інсайд - 'нападник на позиції між центральним та фланговим (лівим чи правим) нападниками' «Інсайди, власне, самі не йшли з м'ячем: вони підігравали центрфорвардові: коли ж центр передавав на край, і край, вийшовши майже до корнерного прапорця, давав паралельний пас під гол, інсайди виходили на шут» (Смолич, «Я вибираю» 593), лівий інсайд 'лівий півсередній нападник' «Коли в шістнадцятому році двоє з чехів футболістів кудись виїхали - лівий край і лівий інсайд, - то якийсь час я лівий інсайд, і Колька Макаревич - лівий край - грали за команду чехів» (Смолич, «Я вибираю» 589), лівий / правий край - 'нападник на лівому / правому краю поля' «3 славних тоді у «Везі» гравців пригадую ще двох прізвища обох забув, але запам'ятались імена: лівий край Гринька рибалка за професією, і правий край - Ронька, апаш» (Смолич, «Я вибираю» 595), капітан «- Решка! - відгукувався капітан одеської команди» (Смолич, «Наші тайни» 161), товариш по команді «I от, відбираючи м'яча, я зіткнувся плече в плече з нашим же правим краєм, моїм товаришем по команді Володькою М.» (Смолич, «Я вибираю» 583), центрхаубек 'центральний півзахисник' «Словом, пригадую, залишились ми троє: я, лівий край - Колька Макаревич та центрхаубек Радивонов» (Смолич, «Я вибираю» 598), партнер «Колективізм для футболіста набирає зовсім реальних, конкретних форм: один проти одинадцяти ти нічого не вдієш, взаємодопомога - завжди запорука перемоги, хочеш уникнути небезпеки страхуй в небезпеці твого партнера» (Смолич, «Я вибираю» 584-585), запасний - 'гравець, який може вийти на заміну' «Їх довелося замінити запасними» (Смолич, «Наші тайни» 162), травмований - 'футболіст, який 
отримав травму' «Рефері припинив гру і підійшов до травмованого» (Смолич, «Я вибираю» 590), хаубек, інсайд, край - 'крайній нападник' ««Водились» тільки по краях, і те - в дрібній пасовці між краєм і хаубеком або інсайдом» (Смолич, «Я вибираю» 592), колишній фбутболіст, лівий інсайд «<...> ми з Майком Йогансеном, поетом, теж колишнім футболістом і теж десять років лівим інсайдом, заходились були створювати футбольну команду «старичків»» (Смолич, «Я вибираю» 601), забивач м'ячів ‘бомбардир' «Але в нашій команді якраз я і був забивачем м'ячів: я йшов на пас з правого фланга - «налітав», як ми тоді казали, - і забивав гол: правою, лівою, «датським», «англійським», «бейтом», головою, грудьми - як прийдеться» (Смолич, «Я вибираю» 593), інструктор по бутболу «Пригадую, вже року двадцять першого чи двадцять другого, коли я був інструктором по футболу у всеобучі <...> (Смолич, «Я вибираю» 593); у східноукраїнському футбольному дискурсі 3-поміж номінацій гравців, відповідно до їхніх функцій на футбольному полі, домінують англізми, тоді, як у Галичині вживано власне українських відповідників: голкіпер воротар; бек - захисник, оборонець, позадній, сторож границі; хаубек напівзахисник, заложник, помічник; форвард - нападач, напасник, передовий; центрфорвард, центр - чільник, середний передовий; інсайд - лучник, злучник; лише питомими назвами в обидвох дискурсах окреслено поняття флангового нападника: на Сході функціювала номінація край, а на Заході крило, криловий; серед родових назв у наддніпрянському футбольному дискурсі за частотністю вживання домінує гібридна лексема футболіст, якій поступається за використанням найменування гравещь, тоді як у Галичині майже безконкуренційно вживано назву грач;

назви ліній футболістів на полі: захист «В захисті грають і чотири, і п'ять, навіть сім гравців» (Смолич, «Я вибираю» 592), півзахист «Півзахист у сучасному футболі першочергово дбає про допомогу своєму захисту - він страхує гравців» (Смолич, «Я вибираю» 592), наnad «I в нападi тепер залишають фактично лише чотирьох, трьох, а то й - останнім часом навіть тільки двох гравців» (Смолич, «Я вибираю» 592), центральна група нападу - 'центральний і два півсередні нападники' «<...> пасовка в центральній групі нападу - ось що мало ціну й захоплювало» (Смолич, «Я вибираю» 591), друга лінія нападу - 'півзахист' «І хаубеки дбали насамперед про те, щоб допомагати нападові - форвардам: вони йшли, власне, другою лінією нападу <...» (Смолич, «Я вибираю» 592), центр 'позиція центрального нападника' «Але про Петьку Пивоварова останнього нашого центрфорварда, що й гастролював «на центрі», - мені хочеться згадати принагідно ще» (Смолич, «Я вибираю» 602); 3-поміж назв функціональних ланок футболістів на полі в творах Юрія Смолича, як і загалом у дискурсі наддніпрянців, переважають, подібно, як це було й у Галичині, питомі лексеми: захист, напад, півзахист, за винятком запозиченої номінації центр; 
назви суддів та інших осіб, причетних до футболу: рефбері «В цей час рефері виймав з кишені срібного карбованця» (Смолич, «Наші тайни» 161), «Рефері припинив гру і підійшов до травмованого» (Смолич, «Я вибираю» 590), суддя «Суддя призначив штрафний в бік воріт команди офіцерів» (Смолич, «Я вибираю» 590), підсудок - 'боковий суддя' «Капітани команд тисли один одному руки й обмінювалися букетами, які зразу ж забирали і виносили за межі поля підсудки» (Смолич, «Наші тайни» 161), «алтик» - 'хлопець, що подає м'яч, який вийшов на авт' «Зрозуміло, що ми «алтики» - відразу ж захопились футболом і почали «ганяти м'яча» по своїх дворах» (Смолич, «Я вибираю» 587), шефб команди «Брати Тубакаєви шефи нашої команди - «династично» закріпили за собою в команді центр» (Смолич, «Я вибираю» 587), начальник команди «Та начальник нашої команди <..> був хлопець «оборотистий» i, щоб не повертатись без відповідної довідки про відбутий матч, того ж дня домовився з командою ОКФ <...>» (Смолич, «Я вибираю» 596), тренер, інструктор - 'тренер' «Завдання було - зробити футбол масовим видом спорту; популяризувати його і мали спеціальні інструктори (термін «тренер» тоді ще не вживався)» (Смолич, «Я вибираю» 594); у назвах суддівського корпусу та найменуваннях осіб, причетних до футболу, переважають запозичення: рефері, тренер, інструктор, шеф команди (у Галичині вживано назв: суддя, голова, роз'ємник, провідник дружини), проте функціювали й питомі номінації: суддя, підсудок (галицьке - суддя межовий) та гібридне утворення начальник команди;

назви суддівських дій: призначити штрафбний «Суддя призначив штрафний в бік воріт команди офіцерів» (Смолич, «Я вибираю» 590), оштрафувати «<..> суддя матчу, не відаючи ще про трагічний результат випадку, оштрафував саме його <...> (Смолич, «Я вибираю» 590); обидві номінації суддівських дій $€$ гібридними утвореннями від запозиченої лексеми штраф; натомість у галицькому футбольному дискурсі твірним словом для називання цих понять стала питома лексема кара - карати, покарати, подиктувати карний коп, диктувати карного;

назви футбольних дій: грати в / у фбттбол «Товаришу! Чи граєте ви у футбол? В футбол треба грати неодмінно» (Смолич, «Наші тайни» 162), «Мого часу у футбол гралося трохи не так, як грається тепер» (Смолич, «Я вибираю» 590), грати «Четверо братів Тубакаєвих теж грали в нашій жмеринській команді» (Смолич, «Я вибираю» 584), «буттболити» 'грати у футбол' «Нам така забавка дуже сподобалась, ми залюбки ходили на уроки гімнастики, щоб «футболити»» (Смолич, «Я вибираю» 586), ганяти м'яча, м'ячика - 'грати в футбол' «Зрозуміло, що ми «алтики»відразу ж захопились футболом і почали «ганяти м'яча» по своїх дворах» (Смолич, «Я вибираю» 587), «<..> батько лаяв: «Таке вже здоровило, а м'ячика ганяє!»» (Смолич, «Я вибираю» 585), бігати з голими коліньми 'грати в футбол' (буквально - 'бігати у футбольних трусах') «А «маси» <...> соромили нас за непристойну поведінку: «Женитись пора, а воно бігає 3 
голими коліньми» (тобто в трусах!)» (Смолич, «Я вибираю» 585), грати головою «Ота шнуровка залишилась у пам'яті футболістів мого часу: коли гралося головою і шнуровка влучала в тім'я, то іскри сипалися з очей, коли ж удар був «кручений» (тепер кажемо «сухий лист»), то й шкіру здирав 3 голови разом із пасмом волосся» (Смолич, «Я вибираю» 586), грати за голкіпера «<..> на літо він приїздив гостювати в Жмеринку, до своїх родичів Тубакаєвих і грав у нашій команді за голкіпера: дуже добрий був 3 нього голкіпер!» (Смолич, «Я вибираю» 584), грати на місці лівого інсайда «І всі десять років гравна одному місці - лівого інсайда» (Смолич, «Я вибираю» 587), грати на лівому фбланзі «Я відразу ж заявив себе форвардом і пішов грати на лівий фланг» (Смолич, «Я вибираю» 587), грати правою ногою, грати обома [ногами] «На лівий тому, що всі грали здебільшого тільки одною правою ногою, а я мріяв про віртуозність і вирішив будь-що навчитись грати обома» (Смолич, «Я вибираю» 587), грати в один доторк - 'копати м'яч, не обробляючи його', пасувати 'копати м'яч партнерові' «Взагалі це було принципом - завжди грати тільки в один доторк, не затримувати м'яча, зразу посилати його партнерові - пасувати» (Смолич, «Я вибираю» 591), грати неповним складом «Найперша причина була в тому, що ми грали неповним складом» (Смолич, «Наші тайни» 162), грати зонально - 'грати в межах закріпленої за футболістом ділянки поля', «підбирати» м'ячі, шутувати по голу 'завдавати удару по воротах', розподіляти м'ячі «Захист в наш час грав виключно зонально: беки пильнували штрафного майданчика, хаубеки кожний своєї половини поля: лівий - зліва до центру, правий - справа, а центральний хаубек завжди йшов висунутий наперед, щоб «підбирати» м'ячі позаду лінії свого нападу і або зразу шутувати по голу через голову свого центрфорварда, або розподіляти м'ячі між інсайдами - для дрібної пасовки, або краями - якщо центр противника виявлявся непробивним» (Смолич, «Я вибираю» 592-593), грати, перегравати «Така була тактика футбола в наш час: залишалась незмінною всі десять років, що я грав; в ній траплялись лише невеличкі зміни, залежно від того, де противник перегравав - по краях чи по центру» (Смолич, «Я вибираю» 593), грати, змагатись, виконувати функцію «алтика» - 'подавати футболістам м'ячі, що виходять в аут', підхоплювати м'яч в ауті, подавати м'яч на поле, вдаряти «Кожний з полків мав свою футбольну полкову команду (грали в повному «умундируванні» й високих чоботях), команди змагалися між собою, і ми - юні жителі сусідніх з полками кварталів жмеринського передмістя Кавказ - виконували функції «алтиків», як тоді казали, тобто підхоплювали м'яч в ауті і подавали його на поле, намагаючись, звичайно, i собі «вдарити»» (Смолич, «Я вибираю» 587), посилати [м'яч] повітрям, приймати [м'яч] на голову, грати «покатюшки» - 'котити м'яч по землі', грати котком - 'котити м'яч по землі' «Посилати його повітрям, а тим паче приймати на голову було неможливо, тож гралося переважно «покатюшки», тобто котком» (Смолич, «Я вибираю» 587), шутувати - 
'копати м'яч без попередньої його зупинки, в один дотик' «Коли назустріч траплялися дівчата, він метко й влучно шутував по них» (Смолич, «Наші тайни» 138), послати м'яч шутом - 'бити в м'яч, не зупиняючи його' «Потім враз <...> сильним шутом послав м’яч далеко через поле на правий край» (Смолич, «Наші тайни» 162), підбирати одбиті м'ячі, шутувати по голу - 'копати м'яч у ворота, попередньо не зупиняючи його' «Макар ішов зліва, трохи позаду, Кульчицький тримався ще далі - він мав підбирати одбиті м'ячі й шутувати по голу через голови ворожого захисту» (Смолич, «Наші тайни» 162), підхопити м'яч головою «Але Сербин підхопив м'яч головою і легко переніс його через ворога» (Смолич, «Наші тайни» 162), підкинути м'яч «Репетюк злегка підкинув м'яч наліво Сербинові» (Смолич, «Наші тайни» 162), перекидати [м'яч] з ноги на ногу, ударити «Сербин, немов знехотя і ліниво, перекинув його з ноги на ногу, потім ударив перед собою вгору» (Смолич, «Наші тайни» 162), приймати пас, вести м'яч по краю, давати пас «Тепер на правому краю Кашин, прийнявши Сербинового паса, мав провести м'яч по краю, майже до корнерного прапорця, унеможливлюючи тим офсайд, і звідтіля давати зрізаний пас під гол» (Смолич, «Наші тайни» 162), налітати на пас 'вибігати назустріч пасові' «Репетюк і Сербин налітали на пас» (Смолич, «Наші тайни» 162), наклепати [голів] - жарг. 'назабивати' «Дарма що на чужому полі, одесити наклепали нам» (Смолич, «Наші тайни» 162), зазнати травми на полі, покалічити супротивника «До того ж, певна річ, я зазнав не однієї травми на полі <..> і сам покалічив не одного супротивника» (Смолич, «Я вибираю» 582), замінити «Їх довелося замінити запасними» (Смолич, «Наші тайни» 162), брати пенальті 'ловити пенальті' «Розповів і про стиль гри преславного голкіпера Дівєєва, надто - як він намертво брав пенальті» (Смолич, «Я вибираю» 584), бити підйомом - 'вдаряти у м'яч підйомом стопи', гатити носком - 'вдаряти у м'яч носком стопи' «Та бити підйомом ми не вміли, гатили носком підметки відривались, черевики «скалили зуби», і в батьків це викликало справедливе обурення» (Смолич, «Я вибираю» 586), катати м'яча, відриватись од противника «<... катаючи м'яча по землі та намагаючись відірватись од противника, ми поступово опановували мистецтвом фінта у «водінні»» (Смолич, «Я вибираю» 587), відігратися «Другий тайм почався навальною атакою офіцерів - вони хотіли за всяку ціну відігратися <...>» (Смолич, «Я вибираю» 589), відтягатись в оборону 'відходити в захист' «Але ми - чехи - не відтягались в оборону, як це робиться завжди тепер проти навальної атаки противника» (Смолич, «Я вибираю» 589), вигравати / виграти «Ми спортові віддавались не для того, щоб вигравати, а для того, щоб мати насолоду від самого грання» (Смолич, «Я вибираю» 591), перемагати «Інтерес полягав у тому, щоб втішно згаяти час і дати вихід молодечому завзяттю, щоб загартуватись фізично, щоб, звичайно, перемагати в змаганні і щоб грати <...> красиво» (Смолич, «Я вибираю» 591), програвати / програти «Програвалими 
чехам і п'ять, і десять голів» (Смолич, «Я вибираю» 589), «I ми знову програли <...>» (Смолич, «Я вибираю» 596), спрямувати м'яч, обіграти суперника «Головне було - радість, яку відчуваєш, коли торкаєшся м'яча ногою та спрямовуєш його саме туди, куди ти хотів, або тільки інтуїтивно відчув, куди тобі його треба спрямувати, щоб обіграти твого суперника <...>» (Смолич, «Я вибираю» 591), вибивати носком, подати вільний від воріт - 'виконувати вільний штрафний удар від воріт' «<...> носком тільки вибивав бек, коли треба було подати вільний від воріт» (Смолич, «Я вибираю» 591), зупиняти м'яч, бити по воротах «Коли ж гравець зупиняв м'яча, а тоді бив по воротах, то вже не був «шут», і прощали його лише в тому випадку, коли був він результативний, тобто м'яч влітав у ворота» (Смолич, «Я вибираю» 591), «водитись» - 'обігрувати суперника, використовуючи оманні рухи’ ««Водились» тільки по краях, і те - в дрібній пасовці між краєм і хаубеком або інсайдом» (Смолич, «Я вибираю» 592), водитись, водити, підігравати ««Водитись» інсайдам суворо заборонялось: водити мав тільки край, і підігравав краєві його хаубек» (Смолич, «Я вибираю» 593), переміщатись назад на допомогу бекам «<...> і лише в хвилини небезпеки, прориву противника, переміщались назад, в глибину, на допомогу бекам» (Смолич, «Я вибираю» 592), «іти на м'яч» - 'виходити назустріч м'ячеві' «Темп гри тепер став незрівнянно вищий: тепер гравець «іде на м'яч», в наш час - чекали, щоб м'яч прийшов до тебе» (Смолич, «Я вибираю» 593), йти з м'ячем, підігравати, передавати на край, давати пас, виходити на шут «Інсайди, власне, самі не йшли з м'ячем: вони підігравали центрфорвардові: коли ж центр передавав на край, і край, вийшовши майже до корнерного прапорця, давав паралельний пас під гол, - інсайди виходили на шут» (Смолич, «Я вибираю» 593), передавати м'яч, пасувати «Адже під ворожим голом у нападі в наш час була фактично одна комбінація: якщо центр не пробивається у штрафний майданчик противника, то передає м'яч на край, а край пасує на гол» (Смолич, «Я вибираю» 593), забити м'яч «Я, наприклад, не мав надто сильного удару - з-поза меж штрафного майданчика я, мабуть, за все своє футбольне життя не забив жодного м'яча» (Смолич, «Я вибираю» 593), грати, забивати / забити гол «<... проти Тіпікіна і Котових грав неодноразово, і навіть забивав Тіпікіну голи» (Смолич, «Я вибираю» 595), «3 наших двох чи трьох я забив один гол: «бейтом» - краси неймовірної» (Смолич, «Я вибираю» 596), йти на пас, «налітати», забивати гол «Але в нашій команді якраз я і був забивачем м'ячів: я йшов на пас з правого фланга - «налітав», як ми тоді казали, - і забивав гол: правою, лівою, «датським», «англійським», «бейтом», головою, грудьми - як прийдеться» (Смолич, «Я вибираю» 593), влітати в гол 'влітати у ворота', збивати голкіпера, штовхати голкіпера в гол 'штовхати воротаря у ворота', тримати м'яч у руках «Часто з м'ячем і сам влітав у гол або збивав з ніг голкіпера, - адже в наш час було дозволено штовхати голкіперав гол, якщо він тримає м'яча в руках» (Смолич, «Я 
вибираю» 593), не давати противникові грати «І хіба ж це інтересно: не давати противникові грати?» (Смолич, «Я вибираю» 592), відбирати м'яч, зіткнутись плече в плече «I от, відбираючи м'яча, я зіткнувся плече в плече з нашим же правим краєм, моїм товаришем по команді Володькою М.» (Смолич, «Я вибираю» 583), штовхати з щільно притиснутою до корпуса рукою «Удар був, очевидно, не такий вже й сильний, бо обидва ми встояли на ногах, але Володька, мабуть, не щільно притис руку до корпуса (щтовхати ж можна лише з щільно притиснутою до корпуса рукою!), і він аж залементував від болю» (Смолич, «Я вибираю» 583), опрацьовувати удари на тренуванні «Удари старанно опрацьовувались на тренуванні і мали свої назви» (Смолич, «Я вибираю» 591), боротись за бутбольну nершість «Звичайно, десь по великих містах - у Києві, Одесі, Петрограді, а надто в містах, що того часу боролись за футбольну першість по цілій країні <...> (Смолич, «Я вибираю» 591), взяти очки, вибити зі змагань «Взяти два очка (за першість) або вибити партнера із змагання (на кубок)» (Смолич, «Я вибираю» 591); однією з найфункціональніших у групі назв футбольних дій є питома лексема грати, яка називає родове поняття грати в футбол (поряд зі значно рідше вживаними синонімічними назвами: футболити, ганяти м'яча, бігати з голими коліньми; у Галичині домінували назви зі стрижневою лексемою копати - копати м'яч, грати 8 копаний м'яч, бавитися в копаного м'яча) та видові найменування - грати головою, грати за голкіпера, грати на лівому фланзі, грати на місці лівого інсайда (гал. - грати на лівому лучнику), грати в один доторк, грати котком (прислівник утворено від прикметника коткий) / покатюшки (прислівник походить від дієслова покотити), грати зонально, грати неповним складом, грати лівою ногою / обома ногами, не давати противникові грати, а також від твірної основи інфінітива грати чи цілого твірного слова утворено похідники - виграти / вигравати, відігратися, перегравати, підігравати, програвати / програти; серед питомих футбольних термінів у творах Юрія Смолича функціює чимало словосполучень із лексемою м'яч: вести м'яч по краю, відбирати м'яч, забити м'яч, зупиняти м'яч, іти на м'яч, йти з м'ячем, катати м'яча, передавати м'яч, перекидати м'яч з ноги на ногу, «підбирати» (одбитий) м'яч, підкинути м'яч, підхоплювати м'ячі головою / в ауті, подавати м'яч на поле, посилати м'яч повітрям, приймати м'яч на голову, розподіляти м'ячі, спрямовувати м'яч; на позначення інших футбольних дій також уживано власне українських лексем і словосполук із питомих складників: бити підйомом (гал. - копати м'яч підбиттям) / по воротах, вдаряти, вибивати носком (гал. - викопувати шпіцом), відриватись від противника, відтягатись в оборону, взяти очки (гал. - (з)добути точки), вибити зі змагань, «водити» / «водитись» (використовувати обманні рухи, фінти, гал. «кивати» / «киватися»), гасити носком, замінити, зіткнутись плече в плече, змагатись, «налітати», обіграти суперника, передавати на край, перемагати, подати вільний від воріт, покалічити противника, ударити 
(гал. копнути, стрілити); зафіксовано чималу групу гібридних футбольних термінолексем, насамперед низку словосполук із запозиченими лексемами nac і шут (удар без попередньої зупинки м'яча) та похідними від них гібридними назвами: давати пас, йти на пас, налітати на пас, пасувати, приймати пас, послати м'яч шутом, шутувати, шутувати по голу, а також інші гібридні номінації: боротись за футбольну першість (гал. - боротьба за першенство у копанім м'ячі), брати пенальті, влітати в гол, забивати / забити гол (гал. - стрілити ворота), зазнавати травми на полі (гал. бути зраненимна полі, бути контузійованим ( змасакрованим), збивати голкіпера (гал. - втрутити воротаря), наклепати голів, опрацьовувати удари на тренуванні (гал. тренувати стріли), переміщуватись назад на допомогу бекам, штовхати голкіпера в гол, штовхати з щільно притиснутою до корпуса рукою; особливість цієї тематичної групи назв пошук питомих відповідників до чужомовних лексем, а відтак запозичення не домінують, як це було серед номінацій інших груп футбольних понять;

назви видів ударів: «кручений» удар - 'удар, коли м'яч летить складною траєкторією', «сухий лист» - 'удар зовнішнім боком стопи в м'яч, який внаслідок цього обертається довкола похилої осі, а на останній ділянці траєкторії різко падає вниз” “Ота шнуровка залишилась у пам'яті футболістів мого часу: коли гралося головою і шнуровка влучала в тім'я, то іскри сипалися з очей, коли ж удар був «кручений» (тепер кажемо «сухий лист»), то й шкіру здирав з голови разом із пасмом волосся» (ЯВЛ, с. 586), штрафбний [удар] «Суддя призначив штрафний в бік воріт команди офіцерів» (Смолич, «Я вибираю» 590), удар з фллангу на флланг, удар 3 фблангу на центр, удар з флангу під гол «Удар! <...> 3 флангу на фланг, з флангу на центр, з флангу під гол <...» (Смолич, «Я вибираю» 591), звичайний удар підйомом, «датський» удар підйомом - 'удар зовнішнім боком підйому” «Удар підйомом був звичайний і був «датський»: зовнішнім боком підйому» (Смолич, «Я вибираю» 591), удар «шпаном» - 'удар внутрішнім боком підйому' «Удар внутрішнім боком підйому звався «шпаном» і використовувався тільки для дрібної пасовки, а взагалі зневажався» (Смолич, «Я вибираю» 591), удар носком, вільний [удар] від воріт «Так само категорично засуджувався удар носком: носком тільки вибивав бек, коли треба було подати вільний від воріт» (Смолич, «Я вибираю» 591), «англійський» удар - 'удар назад через себе', «бейт» 'удар п'яткою через себе наперед' «Зате дуже полюбляли вишукані, «на красу», удари: «англійський» - назад через себе, «бейт» - n'яткою через себе наперед» (Смолич, «Я вибираю» 591), «англійський» «бейт» - 'удар п'яткою через себе наперед' «До «англійського» чи «бейта» нині вдаються тільки в крайньому разі - коли нема іншого виходу із становища, власне коли м'яч вже все одно проминув тебе» (Смолич, «Я вибираю» 593), удар по голу - 'удар по воротах', «шут» - 'удар без попередньої зупинки м'яча', удар «з нальоту» - 'удар з лету', удар в один доторк «Удар по голу звався «шут» і діставав схвалення лише тоді, коли робився «з нальоту», тобто, як 
кажуть тепер, в один доторк» (Смолич, «Я вибираю» 591), [удар] правою, лівою, головою, грудьми, «датський» - 'удар зовнішнім боком підйому', «англійський» «бейт» - 'удар п'яткою через себе наперед' «Але в нашій команді якраз я і був забивачем м'ячів: я йшов на пас з правого фланга «налітав», як ми тоді казали, - і забивав гол: правою, лівою, «датським», «англійським», «бейтом», головою, грудьми - як прийдеться» (Смолич, «Я вибираю» 593), відбійний удар «I ми знову програли: чи 2:5, чи 3:5, незважаючи на блискучу гру нашого голкіпера Мишка Леонова та всі старання беків - Серьожки Боржаковського та особливо Бачинського, що славився неперевершеним відбійним ударом» (Смолич, «Я вибираю» 596); у групі футбольних назв стрижневою є питома лексема удар (у Галичині стріл, коп, вдар); із цим словом утворено власне українські найменування: відбійний удар, звичайний удар підйомом, кручений удар, удар в один доторк, удар головою (гал. - головка), удар грудьми, удар з нальоту (гал. - волей / волєй), удар лівою / правою ногою, удар носком (гал. - вдар / коп шпіцом) та гібридні номінації: англійський удар, «датський» удар підйомом, удар 3 флангу на гол, удар з флангу на фланг, удар з флангу на центр, удар по голу (гал. - стріл), удар «шпаном», штрафний удар (гал. - карний стріл); зафіксовано також питомі назви ударів, утворені метафорично: вільний удар від воріт, сухий лист та кілька запозичених термінів: бейт, англійський бейт, шут;

назви тренувальної підготовки: тренування «За інтенсивними тренуваннями і матчами цього літа, звісно, не лишилося часу на німецькі вокабули та винятки» (Смолич, «Наші тайни» 149), «I грали - забув сказати! - під музику. Звичайно, тільки матчі, а не тренування» (Смолич, «Я вибираю» 592), ігрове тренування «Не знаю, як тепер, а в наш час «ігровим тренуванням» звалась гра в одні ворота - свій напад проти свого захисту: п'ять форвардів проти трьох хаубеків та двох беків» (Смолич, «Я вибираю» 583), спортивний вишкіл «Цій команді чехів ми, власне, і повинні завдячувати за наш спортивний вишкіл <...» (Смолич, «Я вибираю» 589); у цій групі назв конкурують гібридні найменування вишкіл і тренування (у Галичині найфункціональнішими були запозичена лексема тренінг та власне українська назва заправа (від заправлятися тренуватися));

назви особливостей гри: стиль гри «Правда, наш стиль гри був цікавий лише при однаковій кваліфікації противних команд» (Смолич, «Я вибираю» 593), тактика в наступі / обороні, комбінації міжпасовки 'комбінації в перепасовуванні' «Мені ввижалося тоді, на світанку нашого футбола, як команда виробляє свій власний, одмінний від інших команд, стиль гри, свою власну, оригінальну тактику в наступі й обороні; як наперед, у наполегливому тренуванні, відпрацьовуються комбінації міжпасовки <...» (Смолич, «Я вибираю» 600), сучасний / захисний / агресивний стиль гри «Основа сучасного стилю гри - персональна опіка нападника <...>» (Смолич, «Я вибираю» 592), «Нині у футболі переважає 
захисний стиль гри» (Смолич, «Я вибираю» 592), «У наш час, навпаки, суворо дотримувались агресивного стилю» (Смолич, «Я вибираю» 592), тактика футболу - 'тактичні дії футболістів' «Така була тактика футбола в наш час: залишалась незмінною всі десять років, що я грав; в ній траплялись лише невеличкі зміни, залежно від того, де противник перегравав - по краях чи по центру» (Смолич, «Я вибираю» 593), тактика, оборона - 'дії футболістів у захисті', напад - 'дії футболістів у нападі' «Тактика чехів основувалась на іншій концепції: найкраща оборона - це напад» (ЯВЛ, с. 589), атака «І ми ринули в атаку теж» (Смолич, «Я вибираю» 589), темп гри «Темп гри підвищився шалено» (Смолич, «Я вибираю» 589), ритм гри «<...> від ритму музичної п'єси залежав якоюсь мірою і ритм самої гри» (Смолич, «Я вибираю» 592), наступ - 'напад' «<...> коли ж капельмейстер відчував запал до наступу в команді, за яку «болів», він переходив на мазурку» (Смолич, «Я вибираю» 592), наступальна концепція гри «Перевага була - в наступальній концепції гри» (Смолич, «Я вибираю» 592), техніка обробки м'яча «Звичайно, техніка обробки м'яча тепер значно вища: наша була «на красу», тепер - на доцільність» (Смолич, «Я вибираю» 593), точність naca «Для точності паса тепер якнайширше практикується зневажуваний в наш час удар «шпаном»» (Смолич, «Я вибираю» 593), склад команди «Я мріяв про існування постійного складу команди та ії старанне - практичне й теоретичне - тренування» (Смолич, «Я вибираю» 600), система гри «І в цьому був величезний мінус нашої системи гри» (Смолич, «Я вибираю» 593), стратегія змагання, способи комбінаційної гри «Стратегія змагання нині плідно ускладнилась, ускладнились і способи комбінаційної гри» (Смолич, «Я вибираю» 593), противник нижчого класу «Коли ж противник траплявся нижчого класу, то приходило до курйозів» (Смолич, «Я вибираю» 593), правило, перевага «Здається, в наш час було таке правило: якщо забито дванадцять, то змагання на тому й закінчується, фіксуючи тим цілковиту перевагу» (Смолич, «Я вибираю» 594), кваліфбікована гра «Ці команди їздили по частинах і демонстрували квалібіковану гру» (Смолич, «Я вибираю» 594); у групі назв на позначення понять, що окреслюють особливості гри переважають гібридні лексеми: агресивний / захисний / сучасний стиль гри, кваліфікована гра, наступальна концепція, противник нижчого класу, ритм гри, система гри, склад команди, способи комбінаційної гри, стратегія змагання, тактика в наступі / в обороні, темп гри, техніка обробки м'яча, точність паса, невеликий відсоток складають власне українські назви: напад, наступ, оборона, перевага, правило та чужомовні запозичення: атака, комбінація, тактика, тактика футболу;

назви результатів поєдинків та кількісні показники: очки «Хіба до деклінацій та кон'югацій було, коли треба було відбути цілу низку найвідповідальніших міжміських змагань в гонитві за «очками», які давали право пройти в лігові команди?» (Смолич, «Наші тайни» 149), три - один на користь... «Він закінчився три - один, і не на нашу користь» (Смолич, 
«Наші тайни» 162), перемога, програш, виграш «Тепер запекло «болію» не пропускаю жодного матчу «моєї» команди, пристрасно жадаю їй перемоги, тяжко страждаю від кожного ії програшу та пританцьовую на кожний виграш» (Смолич, «Наші тайни» 585), рахунок «Ми закінчували матчі здебільшого з рахунком 5:4, 5:3, 5:2, 4:2, 4:1, 3:1 тощо» (Смолич, «Наші тайни» 592), результат, процес гри «Але більше важив не так результат, як самий процес гри» (Смолич, «Наші тайни» 591), нічийний результат «Тим-то й на рідкість були найпоширеніші тепер «нічийні» результати» (Смолич, «Я вибираю» 592); у групі найменувань результатів футбольних поєдинків та їхніх кількісних показників домінують власне українські лексеми: виграш, очки, перемога, програш, рахунок, рідше вживано гібридні назви: нічийний результат, процес гри і запозичення: результат;

назви вболівальників: глядач «Духовий оркестр патетично вдаряв, і багатотисячною зграєю злітали лопотливі оплески запальних глядачів: 3 корнерних ріжків, одна проти одної, команди вибігали короткими ключами до середини поля» (Смолич, «Наші тайни» 161), болільник 'уболівальник', прихильник «Футбол! Я вимовляю це слово із знаком оклику «!» - тобто з піднесенням аж ніяк не з позиції «болільника»мільйонноголосої формації прихильників цього виду спорту серед наших сучасників» (Смолич, «Я вибираю» 582), вболівальник «Хоча от уже мало не півстоліття після того, як сам зійшов з футбольного поля, теж належу до когорти вболівальників цього чудодійного грища» (Смолич, «Я вибираю» 582); лише питомих назв вжито в творах Юрія Смолича на окреслення футбольних симпатиків: вболівальник, глядач, прихильник (на противагу Галичині, де активно вживався полонізм кібіц); зафіксовано й зросійщений варіант назви - болільник;

назви дій уболівальників: боліти - 'уболівати' «А «болію» вже добрих сорок років» (Смолич, «Я вибираю» 601), не пропускати жодного матчу, жадати перемоги, страждати від програшу «Тепер запекло «болію» - не пропускаю жодного матчу «моєї» команди, пристрасно жадаю їй перемоги, тяжко страждаю від кожного її програшу та пританцьовую на кожний виграш» (Смолич, «Я вибираю» 585), ходити на стадіон, дивитись матч по телевізору «Дарма що після інфарктів на стадіон уже не ходжу і дивлюсь матчі по телевізору, після пританцьовування дістаю задишку, а після м'яча, який влітає в «наш» гол, мушу вдаватись до валідолу чи нітрогліцерину» (Смолич, «Я вибираю» 585); серед назв уболівальницьких дій приблизно однаковий розподіл між гібридними номінаціями: дивитися матч по телевізору, не пропускати жодного матчу, ходити на стадіон та питомими назвами: жадати перемоги, страждати від програшу; зафіксовано й зросійщену форму - боліти;

футбольні вигуки: 2in-2in-ypa - 'вигук-привітання' «Ще тридцять секунд йшли на те, щоб, відскандувавши традиційне «гіn-ypa, zin-ypa, zinура-ура-ура!» - розбігтися на місця до початку» (Смолич, «Наші тайни» 161); ідентичного вигука вживано в Наддніпрянщині й у Галичині. 
Висновки та перспективи дослідження. Проведений аналіз української футбольної лексики, використаної Юрієм Смоличем у художніх текстах, показав, що автор охопив надзвичайно широкий спектр футбольних назв із найважливіших тематичних груп цих номінацій. У статті описано 19 груп футбольних найменувань, 3-поміж яких запозичення домінують у назвах футбольної гри, назвах футбольного поєдинку, його частин та футбольних турнірів, назвах команди та об'єднань команд, назвах ігрових моментів. Переважання питомих одиниць зафіксовано серед назв ліній футболістів на полі, назв уболівальників та їхніх дій, а гібридні найменування домінують у назвах суддівських дій. Українські лексеми та гібридні утворення складають основну частку номінацій у групах назв футбольного спорядження, назв футбольних дій, різновидів ударів, назв тренувальної підготовки, особливостей футбольної гри, а запозичення та гібриди - у назвах футбольних гравців і назвах футбольного майданчика та його частин, натомість чужомовні запозичення та власне українські найменування основа групи назв футбольної форми та групи назв результатів поєдинків та їхніх кількісних показників.

Отже, в художніх творах Юрія Смолича використано найрізноманітнішу лексику основних тематичних груп футбольних назв, у яких загалом домінували запозичення та гібридні номінації, що було специфікою футбольного дискурсу в Наддніпрянській Україні на противагу галицькій мові футболу, в якій у першій половині XX ст. переважали питомі відповідники до чужомовних найменувань.

Перспектива подальших досліджень полягає в аналізі функціювання футбольної термінолексики української мови не лише у звичних для неї текстах наукового та публіцистичного стилів, а також якомога докладніший опис використання футбольних номінацій у творах художнього стилю.

\section{Список використаних джерел}

Смолич, Юрій. «Наші тайни». Смолич, Юрій. Дитинство; Наші тайни; Вісімнадиятилітні. Київ : Наукова думка, 1987, с. 136-377.

Смолич, Юрій. «Я вибираю літературу». Смолич, Юрій. Твори. В 6 m. Т. 6. Київ, 1973, c. 582-602.

\section{Sources}

Smolych, Yurii. "Nashi tainy". Smolych, Yurii. Dytynstvo; Nashi tainy; Visimnadtsiatylitni. Kyiv : Naukova dumka, 1987, pp. 136-377.

Smolych, Yurii. "Ia vybyraiu literaturu”. Smolych Yu. Tvory. 6 vols. Vol. 6. Kyiv, 1973, pp. 582-602.

\section{Список використаної літератури}

Процик, Ірина. “„Копаний м’яч учить боронити і здобувати”: тематична класифікація української футбольної термінолексика кінця XIX - початку XX ст.». Вісник Національного університету «Львівська політехніка»: Серія: Проблеми української термінології, № 842, 2016, с. 151-7. 
Процик, Ірина. «На ціле життя залишився гарячим прихильником копаного м’яча”. Українська футбольна лексика в художніх творах 30-40-х pp. XX ст.». Записки 3 українського мовознавства, вип. 24, т. 1, 2017, с. 318-28.

Процик, Ірина. «Функціювання футбольних термінів першої половини XX століття в художньому тексті». Термінологічний вісник, вип. 4, 2017, с. 281-8.

Струганець, Юрій. Семантика, структура, функціонування футбольної лексики в українській літературній мові початку XXI століття. Автореф. дис. ...канд. філол. наук: 10.02.01. Івано-Франківськ, 2016.

Струганець, Юрій. «Функціонування футбольної лексики у художній мові». Вітчизняна наука на зламі епох: проблеми та перспективи розвитку: матеріали ХХ Всеукраїнської науково-практичної інтернет-конференції (30-31 січня 2016 року, Переяслав-Хмельницький), вип. 20, 2016, с. 122-4.

\section{References}

Protsyk, Iryna. “"Football Teaches to Defend and Gain”: Thematic Classification of Ukrainian Football Terminology at the end of the XIX ${ }^{\text {th }}-$ Beginning of the XX ${ }^{\text {th }}$ Centuries". Herald of L'viv Polynechnic National University "Problems of Ukrainian Terminology", no 842, 2016, pp. 151-7.

Protsyk, Iryna. "'He has become Anardent Supporter of Football for All his Life”. Ukrainian Football Terminology in Literary Works in the 30-40-ies of XX Century". Zapyski Z ukrains'kogo movoznavstva, iss. 24, vol. 1, 2017, pp. 318-28.

Protsyk, Iryna. "Football Terminology of the $1^{\text {st }}$ Half of the $20^{\text {th }}$ Century in the Text". Terminolohichnyi Visnyk, iss. 4, 2017, pp. 281-8.

Struhanets, Yurii. Semantyka, struktura, funktsionuvannia futbolnoi leksyky $v$ ukrainskii literaturnii movi pochatku XXI stolittia. PhD Thesis Abstract. Ivano-Frankivsk, 2016.

Struhanets, Yurii. "Funktsionuvannia futbolnoi leksyky u khudozhnii movi". Vitchyzniana nauka na zlami epokh: problemy ta perspektyvy rozvytku: materialy XX Vseukrainskoi naukovo-praktychnoi internet-konferentsii (30-31 Jan. 2016, Pereiaslav-Khmelnytskyi), iss. 20, 2016, pp. 122-4. 